\title{
Immunization of sheep against GnRH early in life: effects on reproductive function and hormones in rams
}

\author{
B. W. Brown*, P. E. Mattner, P. A. Carroll, E. J. Holland, D. R. Paull, \\ R. M. Hoskinson and R. D. G. Rigby
}

CSIRO, Division of Animal Production, PO Box 239, Blacktown, NSW 2148, Australia

\begin{abstract}
Groups of Merino ram lambs were immunized against GnRH either soon after birth (prepubertal) or around puberty (peripubertal) with a prototype commercial preparation and studied over the following 2 years to determine the long-term effects of such immunization on reproductive development, function and hormone concentrations. The treatment was equally effective in suppressing reproductive function and hormones when given at either time. Growth rates of immunized and controls rams were similar throughout the study. Prepubertal immunization delayed testicular growth until the rams were at least 27 weeks of age and some rams had subnormally sized testes even at 115 weeks of age. After peripubertal immunization, the mass of the testes declined and remained regressed until the rams were from 51 to 90 weeks old. There was a significant correlation between total testicular mass at 115 weeks of age and duration (weeks) of suppression of testicular growth (prepubertal, $r=-0.7375$; peripubertal, $r=-0.7132$, $P<0.001$ ). Prepubertal immunization markedly delayed separation of the penis from the prepuce. The immunized rams did not display sexual activity until their total testicular mass reached at least $70 \mathrm{~g}$. In control and immunized rams with testicular mass $>100 \mathrm{~g}$, the semen did not differ in the percentage of spermatozoa that were unstained (live), of normal morphology, or showed progressive movement. Compared with the increase in plasma $\mathrm{LH}$ and $\mathrm{FSH}$ concentrations with age in control rams, the concentrations of these hormones in the immunized animals were lower and remained relatively constant from 46 to 90 weeks of age. Plasma FSH concentration was particularly suppressed in immunized rams and was significantly $(P<0.05)$ lower than the control values at 61 and 90 weeks of age. $\mathrm{LH}$ release after injection of $1 \mu \mathrm{g} \mathrm{GnRH}$ at 90 weeks of age was either absent or markedly suppressed in immunized rams compared with that for controls.
\end{abstract}

\section{Introduction}

It is well known that repeated immunization of adult male and female domestic animals against the hypothalamic decapeptide gonadotrophin releasing hormone $(\mathrm{GnRH})$ can prevent the production of gonadotrophins and result in the cessation of reproductive function (Jeffcoate et al., 1978, 1982; Robertson et al., 1979, 1982; Schanbacher, 1982). As a result, considerable attention has been paid to the production of practical methods to induce infertility or control of sexual activity in domestic animals through long-term immunity to GnRH.

Although it has been shown that the suppressive effects of anti-GnRH immunization of adult sheep and cattle (Keeling and Crighton, 1984) on reproductive function is reversible

*Present address: CSIRO Division of Animal Production, Clunies Ross St, Prospect NSW 2149 Locked Bag I Delivery Centre, Blacktown NSW 2148, Australia.

Received 19 April 1993. with time, the long-term effects of such immunization when applied to animals early in life has not been thoroughly investigated. Gonadotrophins play a vital role in normal development of the gonads and their cellular components (Courot, 1967), and endogenous GnRH is essential for the maintenance of normal concentrations of pituitary $\mathrm{GnRH}$ receptors (Fraser et al,, 1982; Popkin and Fraser, 1985). A prolonged reduction in the number of pituitary GnRH receptors following immunization against $\mathrm{GnRH}$ (Popkin and Fraser, 1985), together with a concomitant decrease in endogenous LH and FSH concentration during early life, might have some permanent effect on the maturation of the CNS centres controlling reproductive function.

Accordingly, the present study was initiated to examine the duration and severity of effect of an anti-GnRH immunization treatment on subsequent growth, sexual behaviour and reproductive physiology in rams immunized early in life. In addition, the plasma concentrations of the reproductive hormones and the release of $\mathrm{LH}$ and testosterone following injection of $1 \mu \mathrm{g}$ $\mathrm{GnRH}$ were compared with those in control rams. 


\section{Materials and Methods}

\section{Animals and immunization schedule}

Fifty Merino ram lambs born in August were used in this study at Armidale, NSW, until they were approximately 115 weeks of age. They were weaned at 12 weeks of age and maintained at pasture thereafter. Twenty of the lambs each received $1 \mathrm{mg}$ of antigen (see below) in a $2 \mathrm{ml}$ dose (primary dose) at 3-4 weeks of age (prepubertal immunized group) and a boost with the same type and amount of dose at 13-14 weeks of age. Twenty other rams received their primary and booster dose when they were 20-21 weeks and 30-31 weeks of age, respectively (peripubertal immunized group). The remaining ten non-immunized rams served as controls. The primary and booster doses were each injected s.c. at four sites in the neck region. Thirty of these ram lambs (ten from each of the three groups) were used to examine the effects of such immunization on reproductive endocrinology.

\section{Immunogen}

Details of the prototype commercial immunization preparation, which was developed in collaboration with Arthur Webster Pty Ltd, Castle Hill, NSW and Peptide Technology Ltd., Dee Why, NSW, are given by Hoskinson et al. (1990). Briefly, the immunogen was prepared by conjugation of a carboxyl-containing $\mathrm{GnRH}$ analogue to ovalbumin using the diimide reaction. This conjugate was emulsified using a mixture of a solution of $5 \%$ DEAE-dextran $(\mathrm{pH} 7.5)$ in a $50 \%$ water-in-mineral oil emulsion.

\section{Anti-GnRH antibody titre}

At frequent intervals (initially 2 weeks, then $4-6$ weeks) after booster immunization, $5 \mathrm{ml}$ of blood was taken from the jugular vein in all GnRH-immunized rams to monitor antiGnRH antibody titre. Antibody titre was determined for all plasma samples from any one sheep in the same radioligand binding assay, which was similar to that reported for steroids (Abraham, 1974) but using GnRH (specific activity: $100 \mathrm{Ci} \mathrm{mmol}^{-1}$ ). Titre is defined as a dilution of antiserum that bound $50 \%$ of the available radioligand.

\section{Body and testicular growth}

From about 14 weeks of age, the animals were weighed at frequent intervals (every 4-6 weeks) to assess rate of body growth. Coinciding with these times, estimates of total testicular mass (of the two testes) were also obtained using a palpation method described by Oldham et al. (1978), which has been calibrated against actual weights of testes. The period of delayed testicular growth was defined as the time during which no sustainable increase in testicular mass occurred above that at the time of the booster immunization.

\section{Assessment of sexual activity and semen characteristics}

Sexual activity of each control and GnRH-immunized ram was evaluated from the total number of services they performed when individually joined with oestrous ewes in pens for $20 \mathrm{~min}$ on each of two consecutive days (Mattner et al., 1971). At the end of the study, a semen sample was collected from each ram (where possible) using the electroejaculation procedure (Blackshaw, 1954) to evaluate seminal characteristics. The percentages of unstained (live) and morphologically normal spermatozoa were determined from nigrosin-eosin stained smears of semen (Hancock, 1952). The percentage of spermatozoa exhibiting progressive movement was assessed as described by Mattner and Voglmayr (1962) using prewarmed slides and direct microscopy.

\section{Blood sampling and GnRH challenge}

Jugular blood samples $(5 \mathrm{ml})$ were obtained by venepuncture from ten control, ten prepubertal immunized and ten peripubertal immunized rams at intervals of $30 \mathrm{~min}$ for $6 \mathrm{~h}$ when they were 46,61 and 90 weeks of age, to measure mean concentrations of the reproductive hormones. The samples were held on ice until centrifugation (at $5^{\circ} \mathrm{C}$ and $3000 \mathrm{~g}$ for $20 \mathrm{~min}$ ) within $30 \mathrm{~min}$ of collection, and the plasma stored at $-10^{\circ} \mathrm{C}$ until assay. At 90 weeks of age, $1 \mu \mathrm{g} \mathrm{GnRH} \mathrm{(ICl,}$ Melbourne) in $2 \mathrm{ml}$ of $0.9 \%$ saline was injected into a jugular vein in each of three control rams and seven GnRH-immunized rams (which were selected from either immunized group to provide a range in testicular mass), to assess the $\mathrm{LH}$ and testosterone response to a $\mathrm{GnRH}$ challenge. Blood samples $(5 \mathrm{ml})$ were obtained by jugular venepuncture before the $\mathrm{GnRH}$ injection and afterwards, at $10 \mathrm{~min}$ intervals for $1 \mathrm{~h}$ and then at 20 min intervals for a further $2 \mathrm{~h}$.

\section{Hormone assays}

All hormones were measured by radioimmunoassay. The sensitivity of the assays for LH (Radford et al., 1987a) and FSH (Radford et al., 1987b) were 0.19 and $0.06 \mathrm{ng} \mathrm{ml}^{-1}$, respectively. The intra-assay and interassay coefficients of variation (at $50 \%$ displacement of tracer) were all $<10 \%$.

Testosterone concentrations were measured in duplicate. The samples and standards $(20 \mu \mathrm{l})$ were extracted for $5 \mathrm{~min}$ with $2 \mathrm{ml}$ of toluene:hexane $(2: \mathrm{I}, \mathrm{v}: \mathrm{v})$, the solvent phase was evaporated to dryness under $\mathrm{N}_{2}$ and the single antibody technique of Garnier et al. (1978) was then used. An antiserum raised in a sheep against testosterone-3-carboxymethyloximeBSA (M. S. F. Wong and R. I. Cox, CSIRO, Division of Animal Production, Blacktown, NSW) was used at a dilution of 1:60000. Crossreactivity with dihydrotestosterone, 4 -androstene- $3 \beta, 17 \beta$-diol and androstenedione was $31 \%, 30 \%$ and $1.3 \%$, respectively. All oestrogen and progesterone compounds had $<1 \%$ crossreactivity. Mean nonspecific binding was $2.8 \%$; the sensitivity of the assay was $0.1 \mathrm{ng} \mathrm{ml}^{-1}$; and for pooled ovine plasma samples with mean concentrations of 0.6 , 3.5 and $7.3 \mathrm{ng} \mathrm{ml}^{-1}$ the intra-assay and interassay coefficients of variation were $<8 \%$ and $<10 \%$, respectively.

\section{Statistical analyses}

Data were analysed using standard procedures for repeated measures analysis of variance, one-way analysis of variance,
Downloaded from Bioscientifica.com at $64 / 26 / 2023$ 12:39:12PM 
Table 1. Mean ( \pm SEM) body mass $(\mathrm{kg})$ and mean total testicular mass $(\mathrm{g})$ for control and GnRH-immunized rams at different stages in life

\begin{tabular}{|c|c|c|c|c|}
\hline \multirow[b]{2}{*}{ Animals } & \multicolumn{4}{|c|}{ Age (weeks) } \\
\hline & 46 & 61 & 90 & 115 \\
\hline \multicolumn{5}{|l|}{ Control rams } \\
\hline Body mass & $26.2 \pm 1.1$ & $39.8 \pm 1.1$ & $51.8 \pm 1.3$ & $50.4 \pm 1.9$ \\
\hline Testis mass & $101 \pm 12^{a}$ & $242 \pm 24^{a}$ & $214 \pm 10^{a^{*}}$ & $338 \pm 12^{a}$ \\
\hline \multicolumn{5}{|c|}{ Prepubertal immunized rams } \\
\hline Body mass & $25.4 \pm 0.8$ & $43.6 \pm 1.5$ & $48.7 \pm 1.8$ & $50.6 \pm 1.8$ \\
\hline Testis mass & $43 \pm 10^{b}$ & $112 \pm 16^{b}$ & $147 \pm 20^{b}$ & $202 \pm 22^{b}$ \\
\hline \multicolumn{5}{|c|}{ Peripubertal immunized rams } \\
\hline Body mass & $28.3 \pm 0.8$ & $44.1 \pm 1.5$ & $48.3 \pm 1.5$ & $49.5 \pm 1.4$ \\
\hline Testis mass & $23 \pm 3^{b}$ & $79 \pm 12^{\mathrm{b}}$ & $116 \pm 20^{\mathrm{b}}$ & $170 \pm 19^{b}$ \\
\hline
\end{tabular}

Values in any column with different superscripts differ significantly from each other $(P<0.05)$.

*Value probably suppressed owing to effect of season (June) in adult rams (see text).

Student's $t$ test and regression analysis (Minitab, Release 7.2, Minitab Inc., Pennsylvania). After GnRH injection, a positive response (rise in $\mathrm{LH}$ and testosterone) was said to occur when (i) the concentration of the hormone increased by at least $50 \%$ above the preceding baseline value, (ii) there were at least two points between the peak value and the succeeding baseline, and (iii) the rate of decline in concentration after the peak was no greater than that allowed by the half-life of the hormone (Khalid et al., 1987).

\section{Results}

During the course of the study, one prepubertal and two peripubertal immunized rams died from causes unrelated to the immunization treatment.

\section{Anti-GnRH antibody titre}

In all treated animals, the peak anti-GnRH antibody titre response occurred 2 weeks after the booster dose, after which the titre declined at various rates. There were very great differences in antibody titre response between animals (range of 1:2000 to 1:50000) and the magnitude of the peak titre values after the boost could not be related to severity or duration of the effect on testicular development. Furthermore, the magnitude of the peak titre value after the boost was not related to the subsequent rate of decline in antibody titre.

The rate of decline in antibody titre tended to be slower in the rams that had testicular masses $<100 \mathrm{~g}$ at the end of the study than in those that ultimately developed testes $>100 \mathrm{~g}$. Thus, at 20,30 and 60 weeks after booster immunization, the prepubertal immunized rams with small testes had mean circulating antibody titres that were 27,15 and $8 \%$, respectively, of the peak value after the boost, while in all other prepubertal immunized rams, the corresponding values were 9 , 4 and $2 \%$, respectively. Similarly, with the peripubertal immunized rams, there was a tendency for those animals with small testes to have a slightly higher mean antibody titre (as a percentage of the peak value after the boost) from 30 weeks after the booster dose, than for other animals in this immune group. By the end of the study, antibody titres were detectable in only three of the $37 \mathrm{GnRH}$-immunized rams, with the values ranging from 3 to $16 \%$ of the peak titre after the boost (1:500 to $1: 1000)$.

\section{Body and testicular growth}

Throughout the study, the rate of body growth for the two groups of GnRH-immunized rams did not differ significantly from each other or from that for the control rams (Table 1).

For all treatment groups, mean testicular mass increased significantly with increasing age, but the rate of testicular growth differed between the groups. While the group mean values for testicular mass for the prepubertal and the peripubertal immunized rams did not differ materially from each other from 46 to 115 weeks of age, they were significantly $(P<0.05)$ lower than the corresponding values for the control rams (Table $\mathrm{I}$ ).

To understand the trends in testicular development with respect to severity and duration of effect of the treatment, the immunized animals were grouped according to their total testicular mass at 115 weeks of age as follows: those with normally sized testes and in the testicular mass range of the control rams, $>200 \mathrm{~g}$ (range for control animals was $220-360 \mathrm{~g}$ ); those with small testes (juvenile-like), $\leqslant 100 \mathrm{~g}$; and those with medium-sized testes that were substantially smaller than those of control animals, $>100 \leqslant 200 \mathrm{~g}$. In the prepubertal $(n=11)$ and in the peripubertal $(n=6)$ immunized rams that ultimately developed testes in the normal range, the treatment delayed testicular growth from 27 to 46 weeks and from 21 to 44 weeks, respectively. For the immunized animals with small testes at 115 weeks, testicular development was delayed from 51 to 99 weeks for the prepubertal immunized group $(n=4)$ and from 64 to 90 weeks in the peripubertal immunized animals $(n=5)$, but some of the rams in both of these groups exhibited little testicular growth even at 115 weeks of age. At 115 weeks of age, there was a significant correlation between the mean testicular mass and the duration Downloaded from Bioscientifica.com at 04/26/2023 12:39:12PM 
Table 2. Mean ( \pm SEM) service score* for control and GnRH-immunized rams and the percentage of rams serving at various stages in life

\begin{tabular}{|c|c|c|c|}
\hline \multirow[b]{2}{*}{ Animals } & \multicolumn{3}{|c|}{ Age (weeks) } \\
\hline & 61 & 90 & 115 \\
\hline \multicolumn{4}{|l|}{ Control rams } \\
\hline Service score & $3.0 \pm 0.7^{\mathrm{a}}$ & $3.4 \pm 0.5^{\mathrm{a} \dagger}$ & $6.4 \pm 0.6^{a}$ \\
\hline Rams serving (\%) & 90 & 100 & 100 \\
\hline \multicolumn{4}{|c|}{ Prepubertal immunized rams } \\
\hline Service score & $1.3 \pm 0.4^{b}$ & $3.0 \pm 0.6$ & $4.0 \pm 0.6^{b}$ \\
\hline Rams serving (\%) & 50 & 72 & 83 \\
\hline \multicolumn{4}{|c|}{ Peripubertal immunized rams } \\
\hline Service score & $0.9 \pm 0.4^{b}$ & $1.7 \pm 0.5^{\mathrm{b}}$ & $4.1 \pm 0.6^{\mathrm{b}}$ \\
\hline Rams serving (\%) & 25 & 50 & 89 \\
\hline
\end{tabular}

*Service score for individual rams is the total number of services performed in two pen tests of 20 min each conducted $24 \mathrm{~h}$ apart. Values in any column with different superscripts differ significantly from each other $(P<0.05)$.

${ }^{\dagger}$ Value probably suppressed owing to effect of season (June) in adult rams (see text).

(weeks) of suppression of testicular growth (prepubertal, $r=-0.7375$; peripubertal, $r=-0.7132, P<0.001$ ).

\section{Assessment of sexual activity and semen characteristics}

The GnRH-immunized rams showed no interest in mounting oestrous ewes until they had attained a testicular mass of at least $70 \mathrm{~g}$. Rams with testes of $70-100 \mathrm{~g}$ only occasionally served oestrous ewes. For all treatment groups, the mean service score increased significantly $(P<0.05)$ with increasing age (Table 2). The group mean service score for the prepubertal or the peripubertal immunized rams did not differ significantly from each other at any of the age periods studied, but the values for the two immunized groups at 61 and at 115 weeks of age and for the peripubertal immunized rams at 90 weeks of age were significantly lower $(P<0.05)$ than the corresponding values for the control rams (Table 2). The lack of a difference between control and prepubertal immunized animals at 90 weeks of age was possibly due in part to the suppression of libido that occurs in normal adult rams at this time of year (June) in the nonbreeding season (Mattner, 1977). When only the rams that actually served in pen tests were considered, the mean service scores for the immunized and control rams did not differ significantly.

\section{Semen characteristics}

At 46 weeks of age, separation of the penis from the prepuce had occurred in $90 \%$ and $37 \%$ of animals in the control and prepubertal immunized groups, respectively.

In three GnRH-immunized rams with testes $<100 \mathrm{~g}$ at 115 weeks of age, separation of the penis from the prepuce had still not occurred and no semen sample could be obtained. In three other rams in this testis size range in which the penis was free, the ejaculates consisted of seminal fluid devoid of or almost devoid of spermatozoa.

Ejaculates were obtained from all control rams and from all GnRH-immunized rams with testes $>100 \mathrm{~g}$. There was little difference between the control or the immunized animals with respect to the percentage of spermatozoa that were unstained (live), morphologically normal, or showed progressive movement (Table 3).

Although the mean value for the percentage of motile spermatozoa in the ejaculates of the immunized rams with medium-sized testes was low, it was not statistically different from that in ejaculates from control or from the immunized rams with normally sized testes.

\section{Plasma concentrations of testosterone, $L H$ and FSH}

Analysis of the data revealed a significant $(P<0.001)$ effect of age on testosterone concentrations, with the mean values increasing markedly in all groups from 46 weeks to 61 weeks of age (Table 4). The decline in mean concentration of this hormone for the control and the prepubertal immunized rams at 90 weeks of age is probably due to a suppressive effect of the nonbreeding season (Mattner, 1977). The mean circulating concentration of testosterone for the peripubertal immunized group of rams at both 46 and 61 weeks of age was significantly lower $(P<0.02)$ than that for the control rams (Table 4). However, in immunized rams (of either group) and control rams with testes of comparable size, mean plasma testosterone concentrations were of a similar order.

The mean plasma concentrations for LH and FSH increased with age in control animals, but the values were relatively constant from 46 to 90 weeks of age in both groups of immunized rams. As a result, the group mean $\mathrm{LH}$ values for the two immunized groups at 61 weeks of age and their group mean FSH values at both 61 and 90 weeks of age were significantly lower $(P<0.002)$ than the corresponding values for the control rams (Table 4 ).

\section{Responsiveness to GnRH injection}

The endocrine responses obtained in control and immunized rams to an i.v. injection of $1 \mu \mathrm{g} \mathrm{GnRH}$ are shown (Table 5). In Downloaded from Bioscientifica.com at 04/26/2023 12:39:12PM 
Table 3. Semen characteristics of ejaculates obtained from control $(n=10)$ and GnRH-immunized rams with medium-sized $(n=17)$ or normally sized $(n=11)$ testes at 115 weeks of age (values are means \pm SEM)

\begin{tabular}{lccc}
\hline Animals & Live (\%) & $\begin{array}{c}\text { Semen characteristics } \\
\text { Normal (\%) }\end{array}$ & Motile (\%) \\
\hline $\begin{array}{l}\text { Control rams } \\
\begin{array}{l}\text { GnRH-immunized rams } \\
\text { (normal-size testes) }\end{array}\end{array}$ & $73.9 \pm 2.5$ & $85.1 \pm 3.2$ & $79.5 \pm 2.6$ \\
$\begin{array}{c}\text { GnRH-immunized rams } \\
\text { (medium-size testes) }\end{array}$ & $79.6 \pm 2.5$ & $74.7 \pm 4.2$ & $80.6 \pm 5.2$ \\
\hline
\end{tabular}

Data for prepubertal and peripubertal immunized rams are pooled since there were no significant differences between the two immunized groups.

Table 4. Mean ( \pm SEM) concentrations ( $\mathrm{ng} \mathrm{ml}^{-1}$ ) of testosterone, LH and FSH for control $(n=10)$ and GnRH-immunized $(n=20)$ rams at different stages in life, and in relation to mean anti-GnRH antibody titre (the percentage of rams with measurable antibody titre is given in parentheses)

\begin{tabular}{|c|c|c|c|c|}
\hline Hormone & Age (weeks) & Controls & Prepubertal & Peripubertal \\
\hline Testosterone & $\begin{array}{l}46 \\
61 \\
90\end{array}$ & $\begin{array}{l}0.9 \pm 0.2 \\
3.2 \pm 0.6 \\
2.1 \pm 0.7^{\dagger}\end{array}$ & $\begin{array}{l}0.7 \pm 0.1 \\
2.0 \pm 0.5 \\
0.9 \pm 0.2\end{array}$ & $\begin{array}{l}0.3 \pm 0.1^{*} \\
1.3 \pm 0.3^{*} \\
1.5 \pm 0.5\end{array}$ \\
\hline LH & $\begin{array}{l}46 \\
61 \\
90\end{array}$ & $\begin{array}{l}0.3 \pm 0.1 \\
0.6 \pm 0.1 \\
0.8 \pm 0.3\end{array}$ & $\begin{array}{l}0.4 \pm 0.1 \\
0.4 \pm 0.1^{*} \\
0.2 \pm 0\end{array}$ & $\begin{array}{l}0.3 \pm 0.1 \\
0.2 \pm 0^{*} \\
0.3 \pm 0.1\end{array}$ \\
\hline FSH & $\begin{array}{l}46 \\
61 \\
90\end{array}$ & $\begin{array}{l}0.3 \pm 0.1 \\
0.4 \pm 0.1 \\
0.5 \pm 0.1\end{array}$ & $\begin{array}{l}0.3 \pm 0 \\
0.2 \pm 0^{*} \\
0.3 \pm 0^{*}\end{array}$ & $\begin{array}{l}0.2 \pm 0.1 \\
0.1 \pm 0^{*} \\
0.1 \pm 0^{*}\end{array}$ \\
\hline Mean titre & $\begin{array}{l}46 \\
61 \\
90\end{array}$ & & $\begin{array}{l}1: 500(70) \\
1: 450(60) \\
1: 100(20)\end{array}$ & $\begin{array}{l}1: 900(90) \\
1: 600(80) \\
1: 400(60)\end{array}$ \\
\hline
\end{tabular}

GnRH-immunized rams were treated either soon after birth (prepubertal) or around puberty (peripubertal).

Within rows asterisk denotes a significant difference $(P<0.05)$ from control value.

${ }^{\dagger}$ Mean possibly lower because of seasonal effects observed in adult rams.

each of the control rams, there was a marked increase in plasma $\mathrm{LH}$ concentration within $10 \mathrm{~min}$ of the injection of $\mathrm{GnRH}$, followed approximately $20 \mathrm{~min}$ later by a rise in plasma testosterone concentration. A similar response did not occur in any of the GnRH-immunized rams with testicular mass $<100 \mathrm{~g}$. GnRH injection into the immunized rams with testicular mass $\geq 100 \mathrm{~g}$ resulted in peak plasma LH concentrations that were considerably less than those in the controls, and peak plasma testosterone concentrations that were of a similar order to those in control animals (Table 5). Two of the rams with testes $<100 \mathrm{~g}$ had measurable antibody titres that were very low ( 6 and $8 \%$ of the peak antibody titre value after the boost). All other rams injected with $\mathrm{GnRH}$ had no measurable antibody titres.

\section{Discussion}

Immunization of adult animals against $\mathrm{GnRH}$ appears to produce only temporary suppression of gonadal function and sexual behaviour, as reproductive function usually resumes fairly rapidly after decline of antibody titre without any apparent detrimental effects occurring (Robertson et al., 1982; Keeling and Crighton, 1984). In contrast, the present study shows that similar immunization of rams very early in life can produce profound and extremely long-lasting effects on their reproductive capacity, with some of the animals having juvenile-like reproductive organs and a complete lack of libido two years later.

Since many of the immunized rams lacked normal gonadal development long after anti-GnRH antibodies had dissipated, it appears that such immunization early in life may have induced some permanent damage to mechanisms that control reproductive function. Indeed, the results of the present investigation on a selection of these GnRH-immunized animals revealed that their mean plasma gonadotrophin concentration was significantly lower than that of the non-immunized controls. The lower hormone concentrations in the immunized rams at 61 weeks of age is not surprising, since at that time, 14 
Table 5. Peak plasma $\mathrm{LH}$ and testosterone concentrations (ng $\mathrm{ml}^{-1}$ ) in control and $\mathrm{GnRH}$-immunized rams injected with $1 \mu \mathrm{g} \mathrm{GnRH}$ at 90 weeks of age

\begin{tabular}{|c|c|c|c|c|}
\hline Sheep & Response to injection & Peak $\mathrm{LH}^{\mathrm{a}}$ & Peak testosterone $\mathrm{e}^{\mathrm{a}}$ & Testis mass ( $\mathrm{g}$ ) \\
\hline \multirow[t]{3}{*}{ Control rams } & Positive $^{\mathrm{b}}$ & 15.4 & 7.8 & 250 \\
\hline & Positive & 36.9 & 9.2 & 220 \\
\hline & Positive & 23.3 & 7.8 & 250 \\
\hline \multirow[t]{7}{*}{ GnRH-immunized rams } & No response & 0.3 & 0.5 & 40 \\
\hline & No response & 0.4 & 0.8 & 50 \\
\hline & No response & 0.3 & 2.1 & 70 \\
\hline & Positive & 2.2 & 10.7 & 100 \\
\hline & Positive & 8.4 & 3.0 & 130 \\
\hline & Positive & 1.0 & 4.8 & 160 \\
\hline & Positive & 1.4 & 6.8 & 160 \\
\hline
\end{tabular}

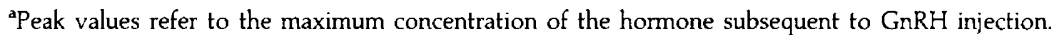

bositive response: a rise in concentration of the hormones following injection of $\mathrm{GnRH}$, in accordance with the defined criteria.

of the 20 immunized animals still had some anti-GnRH antibodies present that could be expected to bind at least some of the circulating $\mathrm{GnRH}$ (titre range: $2-33 \%$ of the peak titre value after the boost). However, at 90 weeks of age, the lower plasma FSH concentrations persisted in both immunized groups of rams, despite the lack of measurable anti-GnRH antibody titres in 12 of the 20 immunized animals and very low titre values for the remainder. Accordingly, these findings indicate that the immunization may have induced some degree of impairment to hypothalamic function, resulting in long-term suppression of $\mathrm{GnRH}$ and of gonadotrophin release in the majority of the immunized rams.

The absence of an $\mathrm{LH}$ response in the immunized rams with small testes $(\leqslant 100 \mathrm{~g})$, or the markedly reduced $\mathrm{LH}$ release (relative to that for controls) in those with testes $\geqslant 100 \mathrm{~g}$ following injection of $\mathrm{GnRH}$ at 90 weeks of age, suggests that the immunization also induced some degree of impairment to pituitary function, resulting in a reduced capacity of the gland either to respond to GnRH stimulation or to produce and release $\mathrm{LH}$ and $\mathrm{FSH}$. However, as the concentration of pituitary $\mathrm{GnRH}$ receptors appears to be under positive autoregulatory control of GnRH (Clayton and Catt, 1981; Popkin and Fraser, 1985), it is possible that the diminished LH response in the immunized animals to $\mathrm{GnRH}$ injection may merely reflect a state of downregulation of pituitary $\mathrm{GnRH}$ receptors due to little or no unbound GnRH in the hypophyseal portal circulation.

The significantly lower mean circulating concentrations of testosterone in the peripubertal immunized rams at 46 and at 61 weeks of age would appear to result from many rams in this immunized group having testes of extremely small size rather than to an inability of the testes to produce this hormone (at 46 weeks of age all peripubertal immunized rams and three control rams had testes $\leqslant 70 \mathrm{~g}$; at 61 weeks of age six peripubertal immunized rams but no control rams had testes $\leqslant 70 \mathrm{~g}$ ). Unlike the LH responses in the immunized animals following $\mathrm{GnRH}$ injection, the peak plasma testosterone concentrations in those immunized rams with testes $\geqslant 100 \mathrm{~g}$ were of a similar order as those in the controls. Consequently, it appears that the testes of the immunized rams may have become more sensitive to $\mathrm{LH}$ stimulation; this feature could account for the ultimate increase in testis mass in the majority of the immunized rams, despite the significantly reduced circulating concentrations of the gonadotrophins. These findings suggest that while the immunization suppressed testicular development, it had no long-term detrimental effect on testicular or Leydig cell function per se and that the normal development of the testes was merely delayed owing to insufficient gonadotrophic stimulation. Once testicular development commenced, immunized and control rams with testes of similar size (irrespective of age) had similar mean plasma testosterone concentrations. It seems likely, therefore, that the size of the testes was the main limiting factor to the production of this hormone in the immunized animals.

In both groups of GnRH-immunized rams, the lower mean libido score occurred as a result of the presence of sexually immature animals and other rams that did not serve, despite them having well-developed testes. Some of the immunized rams with estimated testicular mass between 70 and $100 \mathrm{~g}$ at 115 weeks of age served oestrous ewes, suggesting that while mechanisms facilitating testicular development may be permanently impaired, maturation of the neural centres that regulate sexual behaviour may not be seriously affected by the absence of gonadotrophin or androgens over a period during early life. Once these centres had been activated, the GnRH-immunized rams soon developed service capacity similar to that of untreated controls.

It is well known that expression of sexual behaviour normally precedes the full development and maturation of the testes. Even though, overall, sperm production was considerably reduced in GnRH-immunized rams owing to reduced testicular size, the quality of semen in those rams that developed a testicular mass $>100 \mathrm{~g}$ appeared to be normal. Thus, it is likely that the rams of this class that became sexually active could impregnate at least a proportion of the ewes served by them.

As the anti-GnRH vaccine, whether administered soon after birth or at about the time of onset of puberty, is effective in suppressing gonadal development and sexual activity for considerable periods, commercial producers have wide scope 
for the time of immunization. However, the present data show that the suppressive effects on reproductive function may not be reversible in all treated animals. With appropriate booster immunization schedules, the procedure appears to have potential for use in other animal industries, such as companion animals, as an alternative method to conventional spaying when permanent infertility is required.

The authors are grateful to R. J. Welch, B. E. Harrison and S. Cuthbert for valuable technical assistance and to $P$. Baker of the CSIRO Biometrics Unit for advice on the statistical analysis.

\section{References}

Abraham GE (1974) Radioimmunoassay of steroids in biological materials Acta Endocrinologica 75 (Supplement 183) 7-42

Blackshaw AW (1954) A bipolar rectal electrode for the production of ejaculation in sheep Australian Veterinary Journal 30 249-250

Clayton RN and Catt KJ (1981) Gonadotrophin-releasing hormone receptors: characterization, physiological regulation, and relationship to reproductive function Endocrine Reviews 2 186-209

Courot M (1967) Endocrine control of the supporting and germ cells of the impuberal testis Journal of Reproduction and Fertility Supplement 2 89-101

Fraser HM, Popkin RM, McNeilly AS and Sharpe RM (1982) Changes in pituitary LHRH receptor levels in situations of increased or decreased gonadotropin secretion in the male rat Molecular and Cellular Endocrinology 28 321-333

Garnier DH, Cotta $Y$ and Terqui M (1978) Androgen radioimmunoassay in the ram: results of direct plasma testosterone and dihydroepiandrosterone measurement and physiological evaluation Annales de Biologie Animale Biochimie Biophysique 18 265-281

Hancock JL (1952) The morphology of bull spermatozoa Joumal of Experimental Biology 29 445-453

Hoskinson RM, Rigby RDG, Mattner PE, Huynh VL, D'Occhio M, Neish A, Trigg TE, Moss BA, Lindsey MJ, Coleman GD and Schwartzkoff CL (1990) Vaxstrate ${ }^{\mathbb{B}}$ : An anti-reproductive vaccine for cattle Australian Journal of Biotechnology 4 166-170

Jeffcoate IA, Foster JP and Crighton DB (1978) Effect of active immunisation of ewes against synthetic luteinising hormone releasing hormone Theriogenology 10 323-335
Jeffcoate IA, Lucas JMS and Crighton DB (1982) Effect of active immunization of ram lambs and bull calves against synthetic luteinizing hormone releasing hormone Theriogenology 18 65-77

Keeling BJ and Crighton DB (1984) Reversibility of the effects of active immunization against LH-RH. In Immunological Aspects of Reproduction in Mammals, pp 379-397 Ed. DB Crighton. Butterworths, London

Khalid M, Haresign W and Hunter MG (1987) Pulsatile GnRH administration stimulates the number of pituitary GnRH receptors in seasonally anoestrous ewes Journal of Reproduction and Fertility 79 223-230

Mattner PE (1977) Seasonal variation in libido of intact Merino rams and of testosterone-treated castrates Proceedings of the Australian Society of Reproductive Biology 921

Mattner PE and Voglmayr JK (1962) A comparison of ram semen collected by the artificial vagina and by electro-ejaculation Australian Journal of Experimental Agriculture and Animal Husbandry 2 78-81

Mattner PE, Braden AWH and George JM (1971) Studies in flock mating of sheep. 4. The relation of libido tests to subsequent service activity of young rams Australian Joumal of Experimental Agriculture and Animal Husbandry 11 473-477

Oldham CM, Adams NR, Gherardi PB, Lindsay DR and Mackintosh JB (1978) The influence of level of feed intake on sperm-producing capacity of testicular tissue in the ram Australian Journal of Agricultural Research 29 173-179

Popkin RM and Fraser HM (1985) Changes in pituitary and ovarian LHRH receptors after active immunization of female rats against $\mathrm{LH}$ or LHRH Journal of Reproduction and Fertility 73 491-496

Radford HM, Avenell JA and Panaretto BA (1987a) Some effects of epidermal growth factor on reproductive function in Merino sheep Journal of Reproduction and Fertility $\mathbf{8 0} 113-118$

Radford HM, Panaretto BA, Avenell JA and Turnbull KE (1987b) Effects of mouse epidermal growth factor on plasma concentrations of FSH, LH and progesterone and on oestrus, ovulation and ovulation rate in Merino ewes Journal of Reproduction and Fertility $\mathbf{8 0} 383-393$

Robertson IS, Wilson JC and Fraser HM (1979) Immunological castration in male cattle Veterinary Record 105 556-557

Robertson IS, Fraser HM, Innes GM and Jones AS (1982) Effect of immunological castration on sexual and production characteristics in male cattle Veterinary Record 111 529-531

Schanbacher BD (1982) Responses of ram lambs to active immunization against testosterone and luteinizing hormone-releasing hormone American Journal of Physiology 242 E201-E205 